\title{
Insect and Nematode Control in Cucumber (Cucumis sativus) in Puerto Rico'
}

\author{
Nelia Acosta, Carlos Cruz and José Negrón ${ }^{2}$
}

\begin{abstract}
Field experiments for the chemical control of the pickleworm (Diaphania nitidalis), the melonworm (D. hyalinata), the leafminer (Liriomyza sativae), and nematodes (Meloidogyne incognita and Rotylenchulus reniformis) on cucumber cultivar Ashley were established in two locations in Puerto Rico in 1979 and 1980. In the second test, a lower number of mined leaves was observed on methamidophos-treated plots as well as a significant lower index of leafminer damage. All chemicals controlled the pickleworm effectively. Highest yieids were obtained from plots treated with the highest dosage of acephate and with the intermediate dose of methamidophos. Applications of carbofuran, acephate, methomyl and permethrin reduced the melonworm damage in the third test. Highest yields were obtained from carbofuran-treated plots. All nematicides controlled nematodes in the soil.
\end{abstract}

\section{INTRODUCTION}

Cucumber (Cucumis sativus $\mathrm{L}$.) is one of the most important vegetable crops grown in Puerto Rico. Sixty-six percent of the production obtained during the winter is exported to the United States. In 1982-83, Puerto Rico produced 693,910 kg of cucumbers (2).

Various organisms affect cucumber production, among which insects and nematodes are particularly detrimental. The most serious insect pests are the melonworm (Diaphania hyalinata) and the pickleworm (D. nitidalis). Their life cycles and habits are very similar, except that the melonworm feeds much more extensively on the foliage than does the pickleworm. The melonworm attacks cucumber and pumpkin as well as other cucurbits, but rarely enters the vine or leaf petioles, it is rare in watermelons. The pickleworm attacks mostly the fruit of cucumbers, cantaloupes, and squashes; it rarely attacks watermelons, and pumpkin not at all (8). Some crops are frequently destroyed by these worms.

Other insects associated with cucumber are the leafminer (Liriomyza sativae) and the aphid (Aphis gossypii). The leafminer is present most of the time, but it is more important early in the season when the plants are small and tender. Aphids appear sporadically and only cause severe damage occasionally. But sucking the sap from the leaves, they weaken the plants and reduce both the quantity and quality of the fruit.

Various insecticides have proved effective against some of these insects.

\footnotetext{
' Manuscript submitted to Editorial Board November 29, 1984.

${ }^{2}$ Associate Nematologist, Entomologist and Research Assistant, respectively, Crop Protection Department, College of Agricultural Sciences, Mayagüez Campus, University of Puerto Rico, Mayagiez, P.R.
} 
Adlerz (1) controlled pickleworm (D. nitidalis) in zucchini with applications of methomyl and fenvalerate. Schuster (10) controlled the melonworm (D. hyalinata) and the pickleworm in cucumbers with applications of methomyl, methamidophos and acephate. He also reduced foliar leafminer (Liriomyza sativae) damage with foliar applications of methamidophos and oxamyl.

Various nematodes such as Meloidogyne, Pratylenchus, Rotylenchulus, Helicotylenchus, Tylenchorhynchus and Trichodurus are closely associated with production of cucurbits in Puerto Rico (9). In 1970, 30\% loss on cucumbers was associated with these nematode species. ${ }^{3}$ Román et al. (9) found an increase in yields of pumpkin and watermelon of 52 and $33 \%$, respectively with applications of $16.8 \mathrm{~kg} / \mathrm{ha}$ of fenamiphos $15 \mathrm{G}$. Some chemicals have proved effective for the control of nematodes in cucurbits in the United States $(4,5,6,7,10)$. Johnson and Harmon (4) obtained nematode control with fensulfothion and fenamiphos. Johnson et al. (5) reported the effect of various pesticides on nematodes, weeds and yields of vegetable crops. Nematodes were reduced by soil treatments with an organic phosphate or carbamate nematicide-herbicide-fungicide combination. DD-MENCS, methyl bromide-chloropicrin, ethoprop, carbofuran, and sodium azide + ethoprop or carbofuran. Wright and Rowland (11) reported effective control of $M$. incognita adult females with applications of oxamyl to cucumber roots soon after infection, when mostly 2nd stage juveniles were present in the soil. Littrell (7) reported an increase in yield of $75 \%$ in cucumbers and lower $M$. incognita populations and root-gall indices with applications of oxamyl L. Johnson et al. (6) found higher cucumber yield and lower $M$. incognita populations and root-gall indices with fenamiphos-sprinkler irrigations.

\section{MATERIALS AND METHOOS}

Field experiments were established at Isabela on a Coto clay ( $\mathrm{pH} 7.5$ and $3.6 \%$ organic matter) and at Santa Isabel on a San Antón silt-loam (pH 7.7 and $2.9 \%$ organic matter) with cucumber cultivar Ashley. The target insects were the pickleworm (Diaphania nitidalis), the melonworm (D. hyalinata) and the leafminer (Lyriomyza sativae). The first experiment was established at Isabela in April 1979. Three dosages of the insecticides, acephate $75 \mathrm{~S}(0.56,1.12$ and $2.24 \mathrm{~kg}$ a.i. $/ \mathrm{ha})$, methamidophos $4 \mathrm{E}(0.56,0.84$ and $1.12 \mathrm{~kg}$ a.i./ha), 0.37 of dimethoate and $0.56 \mathrm{~kg}$ a.i. $/ \mathrm{ha}$ of oxamyl, a nematicide-insecticide, were included. Experimental plots with an area of $55.77 \mathrm{~m}^{2}$ were established in April 1979, and consisted of four rows, each $1.83 \mathrm{~m}$ wide and $6.1 \mathrm{~m}$ long. Plant spacing was $1.83 \mathrm{~m}$. All chemicals were applied in $100 \mathrm{gal}$ of water per acre $(2.47 \mathrm{ha})$ to the

\footnotetext{
3'Dr. Jesse Román, Personal Communication.
} 
foliage with a 5-gal knapsack sprayer, one fan nozzle per row, every week throughout the 4-week season, starting 15 days after planting in April. Plants were sprinkled immediately after planting and as needed throughout the season. The experiment consisted of nine treatments replicated four times and arranged in a randomized complete-block design. Untreated plots served as controls. Yield data was recorded for a 30-day period beginning 30 days after planting.

A similar experiment to control $D$. hyalinata and $L$. sativae was established at Santa Isabel in May 1979. Treatments, methodology and plot size were as in the first test except that in this test, plots consisted of two rows, each $1.83 \mathrm{~m}$ wide and $15.24 \mathrm{~m}$ long, and oxamyl $\mathrm{L}$ was not included. Data on yield per plot, and visual damage index (1-5), where 1 represents normal plants and 5 represents the most infested by either leafminer and pickleworm, were recorded 60 days after planting. Data on the percentage of mined leaves were recorded on the basis of 100 leaf samples, the mined leaves of which were counted.

A third experiment to control the melonworm and nematodes was established at Isabela in March 1980. Two dosages (2.24 and $4.48 \mathrm{~kg}$ a.i./ ha) of the granular nematicide-insecticides carbofuran $10 \mathrm{G}$, aldicarb $10 \mathrm{G}$, fensulfothion $15 \mathrm{G}$ at 7.5 and $15 \mathrm{~kg}$ a.i./ha, and ethoprop $10 \mathrm{G}$, at $3.36 \mathrm{~kg}$ a.i./ha were applied to the soil at planting. Plots treated with the lowest and highest doses of carbofuran received 3.36 and $6.72 \mathrm{~kg} / \mathrm{ha}$ (a.i.) respectively 4 weeks after the first application. Oxamyl $L$ at $0.56,1.12$ and $2.24 \mathrm{l} /$ ha was applied to the foliage, $3 \frac{1}{2}$ weeks after planting and weekly up to three applications. Granular nematicides applied by hand from application jars to $30 \mathrm{~cm}$ wide bands were incorporated $5-8 \mathrm{~cm}$ deep with a hoe just before planting. Soil samples for nematode analysis (250 $\mathrm{cm}^{3}$ per plot) were taken $15 \mathrm{~cm}$ deep before nematicide or insecticide application and 5 weeks after application. Nematodes were extracted from the soil following the modified Christie and Perry method (3). The insecticides acephate (1.12 and $2.24 \mathrm{~kg} / \mathrm{ha}$ ), methamidophos $(0.56$ and $1.12 \mathrm{l} / \mathrm{ha})$, methomyl $(0.45 \mathrm{l} / \mathrm{ha})$ and permethrin $(0.2$ and $0.4 \mathrm{l} / \mathrm{ha})$ were also included, as well as untreated controls. Treatments, replicated four times, were included in an incomplete-block design.

Cultural practices, control of weeds, and fertilizer application were those recommended by the Agricultural Experiment Station.

\section{RESULTS AND DISCUSSION}

No significant differences in fruit weight among treatments were obtained in the first test (table 1). Number of fruits from the control plots was significantly higher than those from plots treated with $0.56 \mathrm{~kg}$ / ha of acephate $75 \mathrm{~S}$.

In the second test there were no differences among treatments on the 
percentage of mined leaves (table 2). A significant lower index of leafminer damage was recorded from plots treated with methamidophos (table 2). All chemicals controlled pickleworm effectively. Highest yields were obtained from plots treated with the highest dosage of acephate and with the intermediate of methamidophos. Schuster (10) reduced foliar leafminer ( $L$. sativae) with applications of methamidophos and oxamyl on cucumbers. He also controlled the pickleworm (D. nitidalis) with applications of methamidophos, acephate and methomyl. No data on nematode populations were recorded in the first two experiments.

Results from the third test in table 3 indicate that a lower melonworm damage was obtained with applications of $4.48 \mathrm{~kg} / \mathrm{ha}$ of carbofuran, acephate (1.12 and $4.24 \mathrm{~kg} / \mathrm{ha})$, methomyl and permethrin $(0.4 \mathrm{~kg} / \mathrm{ha})$.

TABI.E 1.-Effects of insecticides and a nematicide-insecticide on the control of insects in cucumber cv. Ashley at Isabela, Puerto Rico, 1979

\begin{tabular}{lcccc}
\hline \multicolumn{1}{c}{ Treatment } & \multicolumn{2}{c}{ Dosage } & \multicolumn{2}{c}{ Fruit yield/plot $^{1}$} \\
\cline { 2 - 3 } \cline { 4 - 4 } & kg (a.i.)/ha & & Number & Weight \\
\hline Acephate 75S & 0.56 & $701.50 \mathrm{a}$ & $351.95^{2}$ \\
Acephate 75S & 1.12 & $868.25 \mathrm{a}$ & 477.05 \\
Acephate 75S & 2.24 & $792.00 \mathrm{ab}$ & 426.50 \\
Dimethoate & 0.56 & $765.75 \mathrm{ab}$ & 406.53 \\
Methamidophos 4E & 0.56 & $835.50 \mathrm{ab}$ & 434.38 \\
Methamidophos 4E & 0.84 & $893.00 \mathrm{ab}$ & 465.60 \\
Methamidophos 4E & 1.12 & $880.00 \mathrm{ab}$ & 474.13 \\
Oxamyl L & 0.56 & $793.50 \mathrm{ab}$ & 476.37 \\
Control & - & $1008.25 \mathrm{~b}$ & 553.10 \\
\hline
\end{tabular}

1 Values in columns with different letters differ statistically at. $5 \%$.

${ }^{2}$ N.S.

Highest yields (fruit number and weight) were obtained with applications of carbofuran. Although a $32 \%$ increase in fruit weight was obtained with the higher dosage of carbofuran, this was not statistically different from the check. This might be due to a high degree of variation among replications within the same treatment. Some treated plots produced less than the untreated plots, which could be attributed to a possible phytotoxic effect by some of the pesticides. Higher yields in carbofuran-treated plots could be the result of its nematicidal effect. This chemical reduced more than $50 \%$ of the nematode populations. All nematicides reduced populations in the soil. Johnson and Harmon (4) controlled nematodes in cucurbits with applications of fensulfothion. Wright and Rowland (11) controlled $M$. incognita adult females with oxamyl I applications and Littrell (7) increased cucumber yields by $75 \%$ with oxamyl, whereas 
TABIE 2.-Effects of inseclicides on the control of lectminer and pickleworm on cucumber cv. Ashley at Santa Isabel, Pluerto Rico. 1979

\begin{tabular}{|c|c|c|c|c|c|c|}
\hline \multirow{3}{*}{ Treatment. } & \multirow{3}{*}{$\begin{array}{c}\text { Dosage } \\
\mathrm{kg} /\left(\text { a.i. }_{\mathrm{i}}\right) \mathrm{ha}\end{array}$} & \multicolumn{2}{|c|}{ Mined leaves ${ }^{1}$} & \multirow{2}{*}{$\begin{array}{l}\text { Pickleworm } \\
\text { dex }(1-5)^{2}\end{array}$} & \multicolumn{2}{|c|}{ Fruit yield/plot } \\
\hline & & \multirow{2}{*}{$\%$} & Damage index $(1-5)^{2}$ & & \multirow{2}{*}{ Number } & \multirow{2}{*}{ Weight } \\
\hline & & & Leafminer & & & \\
\hline & & & & & & $\mathrm{kg}$ \\
\hline Acephate $75 \mathrm{~S}$ & 0.56 & 52.00 & $2.35 \mathrm{ac}$ & $1.48 \mathrm{a}$ & $64.75 \mathrm{a}$ & $44.08 \mathrm{ac}$ \\
\hline Acephate $75 \mathrm{~S}$ & 1.12 & 47.75 & $2.38 \mathrm{ac}$ & $1.43 \mathrm{a}$ & $113.00 \mathrm{be}$ & $68.60 \mathrm{bc}$ \\
\hline Acephate $75 S$ & 2.24 & 51.00 & $2.75 \mathrm{a}$ & $1.55 \mathrm{a}$ & $122.50 \mathrm{bc}$ & $74.13 \mathrm{~b}$ \\
\hline Dimethoate & 0.56 & 47.75 & $2.25 \mathrm{ac}$ & $1.80 \mathrm{a}$ & $71.25 \mathrm{a}$ & $43.88 \mathrm{ac}$ \\
\hline Methamidophos $4 \mathrm{E}$ & 0.56 & 45.25 & $1.68 \mathrm{bd}$ & $1.38 \mathrm{a}$ & 95.25 ac & $50.08 \mathrm{ac}$ \\
\hline Methamidophos $\mathbf{4 E}$ & 0.84 & 46.50 & $1.28 \mathrm{~b}$ & $1.28 \mathrm{a}$ & $118.00 \mathrm{bc}$ & $80.90 \mathrm{~b}$ \\
\hline Methamidophos 4F & 1.12 & 41.75 & $1.55 \mathrm{~b}$ & $1.43 \mathrm{a}$ & $80.00 \mathrm{a}$ & $49.00 \mathrm{ac}$ \\
\hline Control & - & 51.75 & $2.18 \mathrm{~cd}$ & $3.13 \mathrm{~b}$ & $76.50 \mathrm{a}$ & $45.40 \mathrm{ac}$ \\
\hline
\end{tabular}

"Values without letters do not differ statistically at the $5 \%$ probability level.

${ }^{2}$ Damage index $(k-5), 1=$ normal plants and $5=$ most infested; numbers in columns with different letters differ statistically at $5 \%$ level, according to Duncan's multiple range test.

TABLE 3.-Evaluation of insecticides and nematicide-insecticides for the insect and nematode control in cucumber cultivar Ashley, Isabela. 1980

\begin{tabular}{|c|c|c|c|c|c|}
\hline \multirow{2}{*}{ Treatment } & \multirow{2}{*}{$\begin{array}{c}\text { Dosage } \\
\text { kg (a.i./ha) }\end{array}$} & \multirow{2}{*}{$\begin{array}{l}\text { Melonworm }{ }^{1} \\
\text { dariage index }\end{array}$} & \multicolumn{2}{|c|}{ Fruit yield/plot } & \multirow{2}{*}{$\begin{array}{l}\text { Nematode } \\
\text { control }^{2}\end{array}$} \\
\hline & & & Number & Weight & \\
\hline & & & & $k g$ & $\%$ \\
\hline Oxamyl I & 0.66 & $1.9 \mathrm{ac}$ & $380.8 \mathrm{abc}$ & 491.7 abcd & 12.33 \\
\hline Oxamyl L & 1.12 & $2.0 \mathrm{AC}$ & 342.6 bcef & $448.1 \mathrm{bcd}$ & 72.72 \\
\hline Oxamyl L & 2.24 & $1.2 \mathrm{bc}$ & $273.2 \mathrm{c}$ & $350.1 \mathrm{df}$ & 15.00 \\
\hline Carbofuran 10G & $2.24+3.36$ & $1.4 \mathrm{c}$ & $508.1 \mathrm{ag}$ & $623.5 \mathrm{ab}$ & 66.66 \\
\hline Carbofuran $10 \mathrm{G}$ & $4.48+6.72$ & $1.1 \mathrm{~b}$ & $476.1 \mathrm{ad}$ & $635.1 \mathrm{a}$ & 58.82 \\
\hline Aldicarb $10 \mathrm{G}$ & 2.24 & $2.0 \mathrm{ac}$ & 415.8 ae & 496.3 abed & 65.22 \\
\hline Aldicarb 10G & 4.48 & $1.9 \mathrm{ac}$ & 423.3 ae & 549.1 abe & 60.00 \\
\hline Fensulfothion $15 \mathrm{G}$ & 7.50 & $2.0 \mathrm{ac}$ & 410.9 ae & $516.6 \mathrm{abcf}$ & 29.41 \\
\hline Fensulfothion $15 G$ & 15.00 & $1.5 \mathrm{c}$ & 434.6 af & $540.1 \mathrm{abg}$ & 36.36 \\
\hline Acephate $75 \mathrm{~S}$ & 1.12 & $1.0 \mathrm{~b}$ & 291.3 bce & 372.9 cdeg & -31.25 \\
\hline Acephate $75 \mathrm{~S}$ & 4.24 & $1.0 \mathrm{~b}$ & 370.8 bcdef & 485.7 abcd & -36.36 \\
\hline Methamidophos 4S & 0.56 & $1.5 \mathrm{c}$ & 363.1 bedef & 457.8 bed & -50.00 \\
\hline Methamidophos $4 \mathrm{~S}$ & 1.12 & $1.4 \mathrm{c}$ & 366.1 bcdef & 488.0 bed & -63.15 \\
\hline MethomyL L & 0.45 & $1.1 \mathrm{~b}$ & 394.3 abcdg & 604.1 abcd & -185.71 \\
\hline Ethoprop 10G & 3.36 & $1.5 \mathrm{c}$ & $478.7 \mathrm{ad}$ & $415.8 a b$ & 5.88 \\
\hline Permethrin L & 0.20 & $1.2 \mathrm{bc}$ & 324.5 bcef & $346.9 \mathrm{cdeg}$ & -30.00 \\
\hline Permethrin $\mathbf{L}$ & 0.40 & $1.0 \mathrm{~b}$ & $277.3 \mathrm{bc}$ & 482.9 abcdf & -212.50 \\
\hline Check & - & $1.8 \mathrm{c}$ & $390.9 a b c$ & 482.9 abcdf & -44.44 \\
\hline
\end{tabular}

'Damage index (1-5), $1=$ normal plants and $5=$ most infested and damaged; numbers in columns with different letters differ statistically at $5 \%$ level, according to Duncan's multiple range test.

${ }^{2}$ Values without letters do not differ statistically at the $5 \%$ probability level. 


\section{JOURNAL OF AGRICULTURE OF UNIVERSITY OF PUERTO RICO}

Johnson et al. (6) obtained similar results with fenamiphos sprinkler irrigations.

\section{RESUMEN}

Se establecieron experimentos de campo en dos. localidades en Puerto Rico en 1979 y 1980 para investigar el control químico del gusano del pepinillo (Diaphania nitidalis), el gusano de melón (D. hyalinata), el minador (Liriomyza sativae), el áfido (Aphis gossyppi) y los nematodos Meloidogyne incognita y Rotylenchulus reniformis en pepinillo, cultivar Ashley. En el segundo experimento se observó una baja incidencia de hojas con galerias en las parcelas tratadas con metamidophos y un índice de daño del minador significativamente bajo. Todos los productos químicos controlaron el gusano del pepinillo. Las producciones más altas se obtuvieron en parcelas tratadas con las dosis más bajas de acephate y con la dosis intermedia de metamidophos. Las aplicaciones de carbofuran, acephate, metomil y permetrin redujeron el daño del gusano del melón en el tercer experimento. La producción más alta se obtuvo en parcelas tratadas con carbofuran. Todos los nematicidas controlaron los nematodos.

\section{LITERATURE CITED}

1. Adlerz, W. C. 1983. Biology and control of insect pests of vegatables, CRIS, Agrie. Rex. Center, Leisburg, Fla. (Abstr.)

2. Anonymo is, 1983. Estadisticas Agrícolas, Departamento de Agricultura, Puerto Rico.

3. Christie, J. R. and V. G. Perry, 1951. Removing nematodes from soil, Proc. Heiminthol. Soc. Wash. 18: 106-08.

4. Johnson, A. W. and S. A. Harmon, 1974. Cantaloup yield and grade increased by chemical control of Meloidogyne incognita, Plant Dis. Rep. 58: 746-49.

5. - C. A. Jaworski, N. C. Glaze, D. R. Summer and R. B. Chalfant, 1981, Effects of film mulch and soil pesticides on nematodes, weeds, and yields of vegetable crops, J. Nematol. 13: 141-48.

6. - W. A. Rhode and W. C. Wright, 1982. Soil distribution of fenamidophos applied by overhead sprinkler irrigation to control Meloidogyne incognita on vegetables, Plant Disease. 66: 489-91.

7. Littrell R. H., 1983. Nematode control of vegetable with systemic nematicides, CRIs, Georgia Coastal Plain Exp. Stn., Tifton, GA (Abstr.)

8. Metcalf, C. L., W. P. Flint and R. L. Metcalf, 1962. Destructive and useful insects, revised, 4th ed, McGraw-Hill Book Company.

9. Román, J., X. Rivas, I. Reyes and G. Mangual, 1972. Studies on the use of nematicides on vegetable crops, Nematropica 2: 23 (Abstr.)

10. Schuster, D. J., 1982. Arthropod control on cucurbits and eggplant, Proc. Fla. State Hort. Soc. 94: 147-49.

11. Wright, D. J. and A. J. Rowland, 1982. Susceptibility of different development stages of the root-knot nematode, Meloidogyne incognita to the nematicides oxamyl, Ann. Appl. Biol. 100: 521-25. 